\title{
Impersonal Constructions in Igbo
}

\author{
Ihuọma I. Akinrẹmi \\ Department of Linguistics and Nigerian Languages, University of Jos, Nigeria
}

\begin{abstract}
Two major perspectives employed in the characterisation of impersonal constructions in linguistic literature are the subject-centred and the agent-centred perspectives (Siewierska, 2008a). In Igbo studies the impersonal element that has received much attention is the impersonal pronoun a/e, and scholars have generally adopted a subject-based perspective in its analysis, while the agent-based perspective has been largely neglected. In addition, the subject-based perspective of the Igbo impersonal pronoun has generally focused on its distributional properties (Anyanwu, 2005, 2012; Nwaozuzu, 2007), while semantic and functional issues relating to the construction based on the impersonal pronoun has received no serious attention. This limits insight into the range of Igbo constructions that may be considered impersonal under the subject-based perspective. With the aim of locating the impersonal pronoun construction in the larger category of impersonal constructions in the language, the paper adopts a subject-based view of impersonal constructions as those that lack a canonical subject and also applies the agent-based perspective to the Igbo impersonal pronoun in its use as an agent-defocusing strategy. Other Igbo constructions which qualify as impersonal in the light of cross-linguistic criteria established in other studies are identified, and the syntactic and semantic features that make it possible to accommodate such constructions as impersonal, which in previous studies have not been linked to the syntax of the Igbo impersonal pronoun, are also highlighted in the paper.
\end{abstract}

Index Terms - impersonal, pronoun, constructions, functional, cross-linguistic, perspective

\section{INTRODUCTION}

The element traditionally recognised as impersonal in Igbo studies is the impersonal pronoun. It has two forms (ale), which are conditioned by vowel harmony, a restriction on vowel co-occurrence observed in the phonological system of Igbo. The form of the impersonal pronoun used in a sentence belongs to the same harmony group $(a, i, o, u$ or $e, i, o, u)$ as the vowel of the first syllable of the following verbal element, as in the following examples:

(1) a. A gbara bọọl n'ụlọ akwụkwọ. ${ }^{1}$

(IMP shoot.PAST ball in.house book)

'Football was played at school.'

b. A ga-echi ya eze.

(IMP FUT-install him king)

'He will be made king.'

(2) a. E gburu agwọ ụnyaahụ.

(IMP kill.PAST snake yesterday)

'A snake was killed yesterday.'

b. E kwere inyere ya aka.

(IMP agree to.give him/her hand)

'It was agreed upon to give him/her a helping hand.'

The recognition of an impersonal pronoun category in earlier Igbo studies (e.g. Emenanjo, 1978) has come under criticism in some recent studies. Nwaozuzu (2007) argues for a rejection of the category of impersonal pronoun on the basis of the fact that the syntactic features of the impersonal pronoun, including the lack of a plural and a reflexive form, do not qualify it to be a "true pronoun".

The argument is taken further by Anyanwu (2005, 2012), who re-analyses the Igbo impersonal pronoun as a pronominal (subject) clitic, alongside dependent second person and third person singular pronouns, $i / i$ and $o / o$ respectively. In his analysis, pronominal (subject) clitics are distinguished from independent pronouns on the basis of certain syntactic criteria.

This paper aims to show that the impersonal pronoun is only one of the elements used in Igbo to express impersonality and that the Igbo impersonal pronoun construction is only one instance of impersonalization in the Igbo language. Established cross-linguistic criteria for the identification of impersonal constructions will be shown to include as impersonal a number of constructions in Igbo.

\footnotetext{
${ }^{1}$ The following abbreviations are used in the paper: FUT = future marker; IMP = impersonal pronoun; NEG = negative suffix; NP = noun phrase; $\mathrm{PAST}=$ past tense marker; $\mathrm{pl}=$ plural $; \mathrm{PROG}=$ progressive aspect marker; $\mathrm{sg}=$ singular
} 
The paper is organised as follows. Section II provides a characterisation of impersonal constructions based on the two major perspectives on impersonalization in linguistic literature, and Section III outlines Igbo constructions that may be described as impersonal on the basis of cross-linguistic features of impersonals.

\section{CHARACTERISATION OF IMPERSONAL CONSTRUCTIONS}

The lack of consensus in the use of the term 'impersonal' and the wide range of phenomena covered by impersonal constructions (Creissels, unpublished; Siewierska, 2008a, b) make a general definition of impersonal constructions difficult. However, according to Siewierska, 2008a, impersonalization has been characterised from two major perspectives, the subject-centred and the agent-centred perspectives, which sometimes overlap in certain constructions.

The structural point of view of impersonalization is subject-centred, and defines as impersonal constructions that lack a canonical subject, including "(a) those with a subject which is not fully referential, (b) those with a subject which does not display canonical subject properties, (c) those with a subject which is not a verbal argument but merely a place filler..., i.e. an expletive, and (d) those with no overt subject at all" (Siewierska, 2008a, p. 2).

Under the definition of impersonal constructions as those lacking a canonical subject, constructions which have been identified in languages such as French, Finnish, Russian, Breton, Polish, Spanish, French and Greek (Creissels, unpublished; Hewitt, 2002; Siewierska, 2008a) as impersonal include the following:

i. Existential constructions in English, Spanish, Breton and Greek, as in the following examples from Spanish and English.

(3) Spanish (Marsh, 2002, as cited in Siewierska, 2008b, p. 29)

Hay tres estudiantes atrasados

(have three students late )

'There are three late students.'

(4) English (Siewierska, 2008a, p. 5)

There are many linguists in Europe.

ii. Locative constructions in languages such as French and English and Occitan. For example:

(5) French (Hoekstra \& Mulder, 1990, as cited in Siewierska, 2008b, p. 29)

Il est tombé un enfant dans le canal

(it is fallen a child into the canal)

'A chid has fallen into the canal.'

(6) English (Siewierska, 2008a, p. 5)

There's a man at the door.

(7) Occitan (Creissels, unpublished, p. 21)

Davant l'ostal i aviá un òme

(in front of the house there have a man)

'There was a man in front of the house.'

iii. Constructions that express sensations and emotions, in languages like Latin, Icelandic, Finnish, Quechua and

Russian. The following examples are from Irish and Latin, respectively.

(8) Irish (Siewierska, 2008b, p. 27)

Tá ocras orm

'I'm hungry.' (lit. 'Is hunger on me')

(9) Latin (Siewierska, 2008b, p. 27)

Me pundit

'I'm ashamed.' (lit. 'Me shames')

iv. Impersonal passives of intransitive verbs in Lithuanian and German, as in the following example.

(10) German (Kibort, 2004, p. 28)

Es wurde gestern getanzt

it was. $3 \mathrm{sg}$ yesterday danced

'There was dancing yesterday.'

v. meteorological impersonals in Galician, Icelandic, Russian, English and Breton, as in the following Icelandic example.

(11) Icelandic (Siewierska, 2008a, p. 5)

$$
\begin{aligned}
& \text { Bad. Dimmer } \\
& \text { (it darkening) }
\end{aligned}
$$

'It is getting dark.'

The functional perspective in the characterisation of impersonalization is agent-centred. Under this view, an impersonal construction is defined in terms of agent defocusing, which may involve: "(a) the non-elaboration or underelaboration of the instigator, (b) the demotion of the instigator from its prototypical subject and topic function, or (c) both demotion and non-elaboration" (Siewierska, 2008a, p. 7). It is significant to observe that "there is a considerable degree of overlap in the range of constructions which emerge as impersonal under the subject-based and instigator- 
based characterizations of the term. The constructions which are seen to have a non-elaborated or under-elaborated instigator correspond to those lacking a fully referential subject" (Siewierska, 2008a, p.7).

In the case of Igbo, current studies on the impersonal pronoun may be categorised as basically representing the structural or subject-based approach, while the agent-based perspective has been largely unexplored. Nwaozuzu (2007, p. 15) terms the Igbo impersonal pronoun "the unspecified pronominal" and notes that it lacks canonical subject properties, such as having a plural and a reflexive form. She also notes the lack of full referential properties by the Igbo impersonal pronoun, on the basis of which Anyanwu $(2005,2012)$ has classified the impersonal pronoun (along with two other dependent pronouns, $o / O(\mathrm{~s} / \mathrm{he})$ and $i / i$ (you (sg)) as "pronominal subject clitics".

One of the distributional restrictions on the pronominal (subject) clitics (Anyanwu, 2005, 2012) is that they cannot occur in reflexive constructions. The following are examples.

(12) a. ya onwe ya

'He himself/she herself'

b. *o onwe o

'He himself/she herself'

(13) a. gị onwe gị

'You yourself'

b. *ị onwe $\mathrm{i}$

'You yourself'

(14) a. *e onwe e

'Oneself'

b. *a onwe a

'Oneself'

The independent pronouns $y a$ and $g i$ occur in the reflexive constructions (12a) and (13a), while the clitic pronouns cannot be used in the reflexive construction, as the ungrammaticality of (12b), (13b) and (14a, b) indicates.

Furthermore, whereas independent pronouns can occur in coordinate structures, clitic pronouns cannot, as illustrated by (15) through (17).

(15) a. Unu na ya ga-abịa. (you (pl) and him/her FUT-come)

'You (pl) and him/her will come.'

b. Ya na ha ga-abịa.

(s/he and they FUT-come)

'S/he and they will come.'

(16) a. *Unu na o ga-abịa. (you (pl) and him/her FUT-come)

'You (pl) and him/her will come.'

b. *Unu na a ga-abịa.

(you (pl) and IMP FUT-come)

?'You (pl) and someone will come.'

(17) a. Gi na ha riri nri.

(you (sg) and they eat.PAST food)

'You (sg.) and they ate some food.'

b. *I na ha riri nri.

(you (sg) and they eat.PAST food)

'You (sg.) and they ate some food.'

c. *A na ha riri nri.

(IMP and they eat.PAST food)

?'You (sg.) and someone ate some food.'

The examples in $(16 \mathrm{a}, \mathrm{b})$ and $(17 \mathrm{~b}, \mathrm{c})$ indicate that whereas independent pronouns can occur as the first or second conjunct in a coordinate structure, clitic pronouns cannot be so used.

A number of distributional restrictions that distinguish subject clitic pronouns from independent pronouns, such as the ones exemplified by the examples in (12) - (14) and (15) - (17), have been outlined in Anyanwu $(2005,2012)$ and Nwaozuzu (2007). The two authors agree on the fact that the Igbo impersonal pronoun lacks some of the features exhibited by other pronouns in the language. In other words, it is a non-canonical or non-fully referential pronoun under the subject-based or structural perspective.

However, the agent-based perspective has been largely unexplored in the characterisation of the Igbo impersonal pronoun. Torn-Leesik and Vihman (2010) have noted the general assumption often made that "the sole function of the impersonal is to background the agent (p. 308), and have pointed out other pragmatic effects of impersonalization (p. 327). In languages like English, the agent-defocusing or backgrounding function is realised by the passive construction, but although impersonals and passives may be employed to achieve the communicative function of agent defocusing, they have been shown to be two distinct constructions (Blevins, 2003; Torn-Leesik \& Vihman, 2010). 
Cross-linguistic and typological studies of impersonal constructions have led to the establishment of a number of criteria for the identification of impersonal constructions. The subject-oriented (structural) characterisation of impersonal constructions, which includes "those with a subject which is not fully referential" (Siewierska, 2008a, p. 2) and the semantic characterisation that includes as impersonal constructions lacking "a human agent controlling the depicted action" (Siewierska, 2008b, p. 1) are relevant to the identification of impersonal constructions in Igbo.

\section{IGBO IMPERSONAL CONSTRUCTIONS}

Using the criteria outlined in the previous section, impersonal constructions in Igbo would include constructions with a pronominal impersonal subject in episodic and generic readings and a number of constructions with an expletive pronominal subject. In all the Igbo impersonal constructions outlined in this section, impersonalization involves the use of a non-fully referential pronoun or an expletive in the subject position of a clause.

\section{A. The Pronominal Impersonal Construction with an Episodic Reading}

The Igbo impersonal pronoun is a subject-only element. It is not used in any object position - direct, indirect and oblique (Anyanwu, 2005, 2012; Nwaozuzu, 2007). In addition, the Igbo impersonal pronoun is a non-canonical subject in the sense of having non-fully referential features. A construction with the Igbo impersonal pronoun in subject position qualifies as an instance of impersonalization under the subject-centred definition of impersonal constructions as lacking a fully referential subject (Siewierska, 2008a). This is illustrated in the following example.

(18) A ga-elebara ihe ahụ anya.

(IMP FUT-look.into thing the eye)

'The issue will be looked into.'

The impersonal pronoun subject (a/e) is generally used with active, transitive verbs, such as the verb corresponding to look into in (18). The agent of the action denoted by the verb in (18), which is represented by the impersonal pronoun $a$, has an implicit human referent, that is an individual or group that carries out the action. The referent of the impersonal pronoun may include or exclude the speech act participants.

When the impersonal pronoun is used referentially with an episodic reading, as in the examples in (1), (2) and (18), it is possible to reformulate the sentence/clause with a lexical NP or an independent pronoun subject. This important feature distinguishes the referential and expletive uses of the Igbo impersonal pronoun. For example, (18) can be reformulated with a lexical NP or an independent pronoun subject as:

(19) Ada/anyị ga-elebara ihe ahụ anya.

(Ada/we FUT-look.into thing the eye)

'Ada/we will look into the issue.'

The difference between (18) and (19) lies in the nature of the subject element: the non-fully referential impersonal pronoun occupies the subject position in (18), while a lexical NP or an independent pronoun with full referential properties occupies the subject position in (19). A point of interest is why a speaker would use the impersonal pronoun construction (18) instead of a construction with a fully referential subject (19) to refer to the same event. The contrast between the two sentences seems to suggest that in using (18) instead of (19), the speaker chooses to obscure the identity of the agent for some reason. For example, the indefinite or non-fully specified reference of the impersonal pronoun may be used when it is not important or necessary to specify the actor, when the agent of the action is irrelevant or unknown, or when, for some reason, the speaker does not wish, or is unable, to specify the agent of the action. Viewed in this way, the Igbo pronominal impersonal construction is functionally an agent-defocusing strategy in the sense of "non-elaboration of the instigator" (Siewierska, 2008a, p. 7). This accounts for why in the examples (1), (2) and (18), the Igbo impersonal pronoun in subject position serves to background or defocus the agent of the action depicted by the verb. Describing this, Kibort (2004, p. 25) notes that the interpretation of an unspecified agent is associated with the subject in unspecified-agent constructions. The following are further examples of the pronominal impersonal construction with an episodic reading.

(20) E riri ji taa.

(IMP eat.PAST yam today)

'Yam was eaten today.'

(21) A ga-agba ọsọ.

(IMP FUT-run race)

'A race will be run/there will be running.'

The Igbo pronominal impersonal construction in (20) and (21) serves a similar agent-defocusing function as the English agentless passive in their translations. Nwaozuzu (2007) briefly noted the similarity between the two constructions, and noted that a/e is not a full-fledged subject. The cross-linguistic functional equivalence between the basic or synthetic passive in languages that have a passive construction and a construction with an impersonal or indefinite subject in languages without a passive construction has been noted in the literature (e.g. Gregersen, 1977; Keenan \& Dryer, 2006; Sierwierska, 2005). Igbo does not have a passive construction (Nwachukwu, unpublished), and uses an active sentence with an 'impersonal' pronominal element which does not refer to any specific individual in the subject position of the clause to achieve agent demotion or suppression. 
In spite of their functional equivalence, the Igbo pronominal impersonal construction differs from the English passive construction in that it is a morphologically unmarked, structurally active construction, with an impersonal or non-fully referential pronominal element in subject position.

\section{B. The Pronominal Impersonal Construction with a Generic Reading}

The Igbo impersonal pronoun also admits a generic reading. This is an established feature of impersonal subjects (Cabredo-Hofherr, unpublished; Siewierska, 2008a). The generic use of the Igbo impersonal pronoun is employed in the expression of habits, customs and practices, as in (22) - (25).

(22) E ji uche akpata ego.

(IMP use wisdom earn money)

'Money is earned by applying wisdom.'

(23) E ji ego achọ ego.

(IMP use money look.for money)

'One uses money to make more money.'

(24) E ji azịza aza ụlọ.

(IMP use broom sweep house)

'Brooms are used for sweeping.'

(25) A naghị agba aka aga ụka.

(IMP PROG.NEG be.empty-handed go church)

'One does not go to church empty-handed.'

The generic use of the impersonal pronoun also features in proverbs and sayings, as in (26) - (28), taken from Okonkwo (1977, pp. 111-112).

(26) E lelịa nwa ite, ọ gbọnyụa ọkụ.

(IMP despise child pot it boil.quench fire)

'If the little pot is despised, it boils over and quenches the fire.'

(27) A naghị achịrị aka abụa etinye n'ọụ.

(IMP NEG gather hand two put in.mouth)

'One does not put both hands into the mouth at once.'

(28) A chụa aja a hughị udele, a mara na ihe mere na ndị mmụ. (IMP offer sacrifice IMP see.NEG vulture IMP know that something happen.PAST in people.of spirit)

'If there is an animal sacrifice and vultures are not seen, something must have happened in the spirit world.'

The impersonal pronoun (a/e) is used in (22) - (25) as well as (26) - (28) to express actions that are or may be generally done.

\section{Constructions with an Expletive Subject}

This category comprises of constructions in which the subject does not have a human referent or any identifiable referent. The lack of human agency is the feature that qualifies such constructions as impersonal (Sierwierska, 2008a, 2008b). Igbo impersonal constructions in this category would include the following:

i. Existential constructions. This class of impersonal constructions includes those featuring predicates expressing "existential notions of being" (Emenanjo, 1978, p. 141). The following are examples of existential impersonal constructions.

(29) Ọ dị mma/ njọ/ egwu/mfe/mkpa.

(it be goodness/ badness/awe/ ease/importance)

'It is good/bad/awesome/easy/important.

(30) Ọ na-enye m obi ụtọ.

(it PROG-give me heart sweet)

'It gives me joy/pleasure.'

(31) O ruru otu mgbe...

(it reach.PAST one time)

'Once upon a time...'

The subject element in (29) through (31) is the dependent form of the third person singular pronoun, o/o. In the existential impersonal construction, $o / o$ is used as an expletive (dummy) element. Okonkwo (1977, p. 21) refers to this as the impersonal use of $o$.

It is important to note that in this construction, the subject element $o / o$ may be ambiguous between a deictic reading and an expletive one. Examples (29) and (30) illustrate such ambiguity: the subject element $o$ may refer to a person or thing or it may refer to nothing in particular, although such ambiguity is generally eliminated by the discourse context.

A certain use of the verb have to express existential predication has been noted in the literature (Creissels, unpublished; Uriagereka, 1996, as cited in Mbah, 2008). The relevant Igbo expression consists of the third person pronoun $o$ used expletively in subject position with the verb nwe (have) in the indicative verb form (i.e. nwere). The following are examples.

(32) O nwere ka ọ dị. 
(it have like it be)

'It is in a certain manner/state.'

(33) O nwere akụkọ m ga-akọrọ unu.

(it have story I FUT-tell you)

'There is a story I'll tell you.'

The third person singular pronoun in the subject position in (32) and (33) is used impersonally, and does not have any identifiable referent.

ii. Locative constructions. This construction type also uses the verb nwere. Mbah (2008) has noted that the use of nwere is ambiguous between integral and locational meanings. The subject position of the locative construction is occupied by the third person singular pronoun $o$, which is used expletively, as in (34) and (35).

(34) O nwere nwooke kwụ ebe a n'ụtụtụ.

(it have man stand place this in.morning)

'There was a man standing here in the morning.'

(35) Onwere ihe di n'ime ite.

(it have something be at.inside pot)

'There is something inside the pot.'

The impersonal pronoun $e$ may also be used in the locative construction, not in the referential sense of referring to an unspecified person or group, but as a semantically empty (expletive) element. For example:

(36) E nwere mmiri n'ebe a.

(IMP have water in.place this)

'There is water in this place.'

(37) E nwere ọtutu ugbo ala n’ọnịcha.

(IMP have many vehicle land in.Onicha)

'There are many cars in Onicha.'

The expletive use of the impersonal pronoun is also found in idiomatic expressions such as $e$ mee ('later on'), $e$ nwere ike ('it is possible'), e nweghi ike ('it is not possible'); e kwesiri ('it is necessary'), as used the following examples.

(38) E mee, ị gaa kpọo ha.

(IMP do you go call them)

'Later on, you will go and call them.'

(39) $\mathrm{E}$ nwere ike inye gị nri.

(IMP have power to.give you food)

'You may be given food/it may be possible to give you food.'

(40) E nweghi ike ịchọta ya.

(IMP have.NEG power to.find it)

'It cannot be found/it is not possible to find it.'

(41) E kwesiri ikele ha.

(IMP ought to.thank them)

'They ought to be thanked/It is necessary to thank them.'

The impersonal pronoun $e$ in (38) through (41) is used in idiomatic expressions of notions like possibility, impossibility and necessity, although human agency may be implied.

iii. The subject raising construction. There is a parallel between the English raising construction (42) and the Igbo raising construction (43).

(42) a. [NP $e$ ] is likely [John to leave.] (Carnie, 2002, p. 228)

b. $\mathrm{John}_{\mathrm{i}}$ is likely $\left[t_{\mathrm{i}}\right.$ to leave]

(43) a. Ọ dị ka [mmiri ga-ezo.] (Nwachukwu, 1995, p. 186)

(it be like water FUT-rain)

'It is likely to rain.'

b. Mmiri ${ }_{i}$ dị ka [ọi ga-ezo.]

(water be like it FUT-rain)

'Rain is likely to fall.'

The surface subject of the raising predicate is likely in (42b) is assumed to originate as the subject of the embedded clause (in (42a)), from where it is raised to the empty matrix subject position (Carnie, 2002; Radford, 1988). A similar analysis is proposed for the Igbo examples in (43). The matrix subject element $o$ in (43a) corresponds to the English pleonastic element 'it' (Nwachukwu, 1995). Therefore the matrix subject position in (43a) is semantically empty. Movement of the embedded clause subject in (43a) through subject raising yields (43b), in which the NP position made empty by subject raising is filled by the resumptive pronoun, $O$.

Igbo raising structures like (43a) are impersonal to the extent that the expletive element in their subject position is a non-canonical subject element. 


\section{CONCLUSION}

The paper has explored the range of Igbo constructions which may be regarded as impersonal. The subject-centred and agent-centred perspectives were utilised to highlight the semantic and functional features that characterise impersonal constructions in Igbo. On the basis of cross-linguistic criteria established in other studies, certain constructions in Igbo were shown to be typically impersonal. These include the pronominal impersonal construction in both its episodic and generic readings. A functional view of the Igbo impersonal pronoun in its episodic reading illustrated its use as a strategy for agent defocusing or backgrounding in a construction that is equivalent to the English agentless passive and is sometimes translated with English one. Also identified as impersonal are existential constructions, locative constructions and subject raising constructions, which are characterised by a pleonastic or semantically empty subject element. It is striking to note that, like the impersonal pronoun, the pleonastic elements used in other impersonal constructions are all subject position elements. This similarity in distribution suggests that impersonalization is associated with the subject position in the Igbo clause, which serves to accommodate a non-fully referential pronoun to achieve agent defocusing, as in the case of the impersonal pronoun, or a semantically empty expletive in existential, locative and subject raising constructions.

\section{REFERENCES}

[1] Anyanwu, O. (2005). Pronominal clitics in Igbo. Journal of the Linguistic Association of Nigeria (JOLAN) 9, 39-55.

[2] Anyanwu, O. (2012). Pronominal subject clitics in Igbo. Theory and Practice in Language Studies 2.2, $377-388$. doi:10.4304/tpls.2.2.377-388 (accessed 3/9/2012).

[3] Blevins, J. P. (2003). Impersonals and passives. Journal of Linguistics 39, 473-520.

[4] Cabredo-Hofherr, P. (unpublished). 'Binding properties of impersonal human pronouns in generic and episodic contexts.' Paper presented at Workshop on Impersonal Human Pronouns, UMR 7023 Structures formelles du langage CNRS /Université Paris-8, Paris, France. Retrieved from http://www.umr7023.cnrs.fr/Programme,882.html (accessed 6/10/2012).

[5] Carnie, A. (2002). Syntax: A generative introduction. Malden, MA: Blackwell Publishing.

[6] Creissels, D. (unpublished). Impersonal and related constructions. Lectures, University of Tartu. Retrieved from http://deniscreissels.fr (accessed 9/10/2012).

[7] Emenanjo, E.N. (1978). Elements of modern Igbo grammar. Ibadan: Oxford University Press.

[8] Gregersen, E. (1977). Language in Africa: An Introductory survey. New York: Gordon and Breach.

[9] Hewitt, S. (2002). The Impersonal in Breton. Journal of Celtic Languages 7, 1-39.

[10] Keenan, E. L. \& M. S. Dryer. (2007). Passive in the world's languages. In T. Shopen (ed.), Clause structure, language typology and syntactic description (Vol. I, $2^{\text {nd }}$ edn.). Cambridge: Cambridge University Press, 325-361.

[11] Kibort, A. (2004). Passive and passive-like constructions in English and Polish. Doctoral Diss. University of Cambridge Research Centre for English and Applied Linguistics.

[12] Mbah, B. M. (2008). Di and Nwere: Towards a semantic study of integral and locational predication in Igbo. In O. Ndimele, I. I. J. Udoh \& O. Anyanwu (eds.), Critical issues in the study of linguistics, languages and literatures in Nigeria: A festschrift for Conrad Max Benedict Brann. Port Harcourt: The Linguistic Association of Nigeria, in conjunction with M \& J Grand Orbit Communications, 465-472.

[13] Nwachukwu, P. O. (unpublished). A journey through the uncharted terrain of Igbo linguistics. $16^{\text {th }}$ Inaugural Lecture, University of Nigeria, Nsukka. Retrieved from http://www.unn.edu.ng/files/Inaugural\%2520 (accessed 16/8/2012).

[14] Nwachukwu, P. O. (1995). Topic, focus and move-alpha in Igbo. In E. N. Emenanjo \& O. Ndimele (eds.), Issues in African languages: Essays in honour of Kay Williamson. Aba, Nigeria: National Institute for Nigerian Languages, 181-192.

[15] Nwaozuzu, G.I. (2007). Erroneous assumptions in the description of some aspects of indigenous Nigerian languages: The case of the unspecified pronominal element in Igbo. In B. N. Anasiudu, G. I. Nwaozuzu \& C. N. Okebalama (eds.), Language and literature in a developing country: Essays in honour of Prof. B. O. A. Oluikpe. Onitsha: Africana-First Publishers, 15-27.

[16] Okonkwo, M. N. (1974). A complete course in Igbo grammar. Lagos: Macmillan.

[17] Radford, A. (1988). Transformational grammar. Cambridge: Cambridge University Press.

[18] Siewierska, A. (2005). Passive constructions. In M. Haspelmath, M. S. Dryer, D. Gil, \& B. Comrie (eds.), The world atlas of language structures. Oxford: Oxford University Press, 434-437.

[19] Siewierska, A. (2008a). Introduction: Impersonalization from a subject-centred vs. agent-centred perspective. Transactions of the Philological Society 106, 1-23.

[20] Siewierska, A. (2008b). Ways of impersonalizing: Pronominal vs. verbal strategies. In M. G. Gómez, J. L. Mackenzie \& E. M. G. Álvarez (eds.), Current trends in contrastive linguistics: Functional and cognitive perspectives. Amsterdam: John Benjamins, 3-26.

[21] Torn-Leesik, R. \& V. Vihman. (2010). The uses of impersonals in spoken Estonian. SKY Journal of Linguistics 23, 301-343.

Ihuọma I. Akinrẹmi is a lecturer at the Department of Linguistics and Nigerian Languages, University of Jos, Nigeria. She obtained her BA, MA and PhD degrees from the University of Jos, Nigeria. Her research interests are Igbo and Hausa syntax, and syntactic aspects of language contact phenomena. She has published papers in these areas. Dr. Akinremi is a member of the Linguistics Association of Nigeria (LAN), and a fellow of the African Humanities Program (AHP) of the American Council of Learned Societies (ACLS). 